\title{
Mites associated with sugarcane crop and with native trees from adjacent Atlantic forest fragment in Brazil
}

\author{
Mércia E. Duarte ${ }^{1}$ Denise Navia ${ }^{2}$ Lucas R. dos Santos ${ }^{3}$. \\ Pedro J. S. Rideiqui ${ }^{3} \cdot$ Edmilson S. Silva $^{3}$
}

Received: 13 October 2014/Accepted: 30 April 2015/Published online: 24 May 2015

(C) Springer International Publishing Switzerland 2015

\begin{abstract}
In some Brazilian regions the Atlantic forest biome is currently restrict to fragments occurring amid monocultures, as sugarcane crops in the Northeast region. Important influence of forest remnants over mite fauna of permanent crops have been showed, however it has been poorly explored on annual crops. The first step for understanding ecological relationship in an agricultural systems is known its composition. The objective of this study was to investigate the plant-inhabiting mite fauna associated with sugarcane crop (Saccharum officinarum L.) (Poaceae) and caboatã (Cupania oblongifolia Mart.) (Sapindaceae) trees in the state of Alagoas, Brazil. Sugarcane stalks and sugarcane and caboatã apical, middle and basal leaves were sampled. A total of 2565 mites were collected from sugarcane and classified into seven families of Trombidiformes and Mesostigmata orders, with most individuals belonging to the Eriophyidae, Tetranychidae and Tarsonemidae families. Among predatory mites, the Phytoseiidae were the most common. A total of 1878 mites were found on C. oblongifolia and classified into 13 families of Trombidiformes and Mesostigmata orders. The most abundant phytophagous mite family on caboatã was also Eriophyidae. In contrast to sugarcane, Ascidae was the most common predatory mite family observed in caboatã. No phytophagous species were common to both sugarcane and $C$. oblongifolia. However two predatory mites were shared between host plants. Although mites associated with only one native species in the forest fragment were evaluated in this study, our preliminary results suggest Atlantic forest native vegetation can present an important role in the sugarcane agricultural system as a source of natural enemies.
\end{abstract}

Mércia E. Duarte

mercia_elias@hotmail.com

1 Centro de Ciências Agrárias (CECA- UFAL), Universidade Federal de Alagoas, Rio Largo, Alagoas 57100-000, Brazil

2 Embrapa Recursos Genéticos e Biotecnologia, Brasília, Distrito Federal 70770-900, Brazil

3 Universidade Federal de Alagoas, Campus Arapiraca, Arapiraca, Alagoas 57309-005, Brazil 
Keywords Saccharum officinarum - Cupania - Phytophagous mites · Predatory mites · Agricultural systems

\section{Introduction}

Plant-inhabiting mites are important components of agroecosystems, and they exhibit diverse feeding habits including phytophagous, predatory, mycophagous and saprophytic species. Many phytophagous mite species are considered pests in major crops (Hoy 2011). Phytophagous mites usually become pests because they were displaced from their original natural environments to new areas in the absence of their natural enemies. Certain phytophagous mite species also become pests in their natural environments due to habitat changes that highly favor mite development and difficult the development of natural enemies (Moraes and Zacarias 2000). Many predatory mite species, which are potential natural enemies of agricultural pests, may be disappearing even before being identified, as a consequence of the intense devastation of natural environments primarily due to human activities (Demite and Feres 2005).

In some Brazilian regions Atlantic forest is currently restrict to fragments occurring amid monocultures. Natural areas may provide alternative foods and habitats for the natural enemies of phytophagous mites infesting crops. Understanding the ecological relationship and dynamics of the acarofauna in agricultural crops and in the surrounding vegetation is crucial for the sustainable management of the current agricultural systems (Demite and Feres 2008). The remaining Atlantic forest in some Northeastern Brazilian states are small fragments embedded in a matrix of sugarcane and human infrastructure (MMA 2006).

Sugarcane (Saccharum officinarum L.) crop has a high economic value and is widely distributed throughout Brazil. The major sugarcane-producing states are located in the Southeast and Northeast regions of the country. The area cultivated with sugarcane destined for sugar and alcohol production in the 2013-2014 was estimated at 8,799,150 thousand hectares, with a yield of over 652 million tons. The sugarcane-cultivated area in the State of Alagoas, the largest sugarcane producer in Northeastern Brazil, is 442,590 hectares, with a yield of over 24 thousand tons, representing more than $5 \%$ of the national production (Conab 2013).

Seven phytophagous mite species have been reported on sugarcane in Brazil, from three families: Abacarus sacchari Channabasavanna (Eriophyidae); Steneotarsonemus bancrofti Michael and Steneotarsonemus brasiliensis Flechtmann (Tarsonemidae); Monoceronychus linki Pritchard and Baker, Schizotetranychus sacharum Flechtmann and Baker, Oligonychus pratensis (Banks), and Oligonychus grypus Baker and Pritchard (Tetranychidae)—some of them have been reported to damage sugarcane (Moraes and Flechtmann 2008).

Plant diversity within Atlantic forest fragments is reported for several families, including the Sapindaceae family, which consists of trees, shrubs or vines, distributed mainly in tropical and subtropical regions (Barroso 1991). In total, 24 genera and approximately 400 species of Sapindaceae occur in Brazil (Lorenzi and Souza 2008). The genus Cupania L. is one of the most common in the Atlantic forest (Herculano and Matos 2008). In the State of Alagoas the species Cupania oblongifolia Mart. is often found in forest fragments adjacent to sugarcane crops. Some Cupania species are used in popular medicine, as well 
as in landscaping, mainly in urban forestry. Cupania species are also considered highly useful in mixed plantings intended for the recovery of degraded areas because is adapted to direct sunlight (Lorenzi 2000; Brandão et al. 2002).

The only known study regarding herbivore exploitation or inquilinism of Cupania by Arthropoda, especially mites, was conducted by Romero and Benson (2005). These authors reported the occurrence of Eriophyidae mites and certain predators associated with $\mathrm{Cu}$ pania vernalis Camb in an area of semi-deciduous forest in the Serra do Japi, southeast Brazil.

In Neotropical regions, plant-inhabiting mites are highly diverse but little-known. Information regarding mites associated with sugarcane crops and species of Atlantic forest remnants remains scarce. This study aimed to investigate the plant-inhabiting mite fauna, including phytophagous and predatory species, associated with sugarcane crops and the most common native tree in adjacent Atlantic forest fragments, $C$. oblongifolia. Provided information is the first step for understanding ecological relationship among sugarcane crop and $C$. oblongifolia mite fauna and subsequently evaluate influence of these native plants on the phytosanitary conditions of the sugarcane crop.

\section{Materials and Methods}

This study was conducted in areas of sugarcane cultivation and in an Atlantic forest fragment known as Madeiras Reserve $\left(9^{\circ} 52^{\prime} \mathrm{S}, 36^{\circ} 19^{\prime} \mathrm{W}\right.$ to $9^{\circ} 52^{\prime} \mathrm{S}, 36^{\circ} 20^{\prime} \mathrm{W}, 79-157$ asl). Both areas belong to the refining sugar and ethanol plant Reunidas Seresta, located between the cities of Junqueiro and Teotônio Vilela, Alagoas, Brazil. Each area measures approximately 200 hectares.

For the collection and transportation of zoological material, a permanent license for collecting zoological material, granted by the Chico Mendes Institute for Biodiversity Conservation (ICMBio) and Ministry of Environment (MMA), registered under number 32863-1 was obtained.

Samples were collected over three seasons, in February, June and August, 2012, corresponding to the summer, fall and winter seasons, respectively. The rainfall and temperature mean observed in these months were, respectively, $106.5 \mathrm{~mm}$ and $27^{\circ} \mathrm{C}$, $235.0 \mathrm{~mm}$ and $22.5{ }^{\circ} \mathrm{C}$, and $233.0 \mathrm{~mm}$ and $22.2^{\circ} \mathrm{C}$. The meteorological data were obtained from the weather station of Reunidas Seresta plant.

Sugarcane leaves were collected in the four quadrants from six ratoons randomly chosen throughout the cultivated area. Four leaves were sampled from the apical, middle and basal strata each. A plant of the same ratoon was also collected for sampling mites from the stalk.

A prior observation of native plants density in the Atlantic forest fragment was performed to decide what species would be sampled. Cupania oblongifolia was chosen because it is a common native tree in Atlantic forest fragments surrounding sugarcane crops in this state. Samples were collected from six plants within four quadrants by taking leaves from the apical, middle and basal strata, as was done for sugarcane.

Plant/leaf samples were stored in paper bags wrapped in a plastic bag. Next, all of the sampled material was stored in properly labeled bags, and moved to coolers refrigerated with Gelo- ${ }^{\circledR}$. The cooler was used to keep the temperature near $21{ }^{\circ} \mathrm{C}$ and thus avoid mortality and/or escape of the mite specimens. 
All the material was sent to the laboratory of entomology/acarology, of the Arapiraca Campus and the Center of Agricultural Sciences (Centro de Ciências Agrárias-CECA) of Federal University of Alagoas (Universidade Federal de Alagoas-UFAL). Samples were inspected using a stereomicroscope (40× magnification) and extracted using a fine brush.

The specimens found were counted, collected and stored in plastic Eppendorf ${ }^{\circledR}$ tubes containing a $70 \%$ alcohol solution. Afterward, mites were mounted on microscope slides with Hoyer's medium (Krantz and Walter 2009), which were kept in an oven for 7 days at $50{ }^{\circ} \mathrm{C}$ until sealing.

The mites were classified into superfamily/family at the laboratories of Entomology/ Acarology of the, UFAL Arapiraca Campus and CECA using an optical microscope and consulting the dichotomous keys by Krantz and Walter (2009). The mite species of the superfamily Eriophyoidea were identified in the Laboratory of Plant Quarantine at the Embrapa Genetic Resources and Biotechnology, Brasília, Federal District. The identification of the mites within other superfamilies was confirmed with the assistance of Dr. Gilberto José de Moraes, from the Acarology Laboratory, Department of Entomology, Plant Pathology and Agricultural Zoology, Luiz de Queiroz College of Agriculture, São Paulo University (Universidade de São Paulo-USP), in Piracicaba, São Paulo. The identification to genus or species level was performed using an phase and differential interference contrast (DIC) microscope and consulting keys specific to each family. Additionally, comparisons with specimes deposited in the collections of the mentioned institutions were made whenever possible. Original descriptions and redescriptions were also consulted.

In the count of mites belonging to the different order/families immature stages as well as adults were considered (see Tables 1 and 2). Identification of genera and species was possible only when adults were available. Eriophyidae mites collected from C. oblongifolia were counted jointly, since it was no possible mount all specimens and posteriorly more than one species was identified (see Table 3).

The slides were numbered, labeled and stored in adequate boxes after identification. The specimens were deposited in the collections of the following institutions: Laboratory of the Plant Quarantine at the Embrapa Genetic Resources and Biotechnology, Brasília, Federal District, of the Zoology and Botany Department, Universidade Estadual Paulista (UNESP), São José do Rio Preto, São Paulo, Department of Entomology, Plant Pathology and Agricultural Zoology, ESALQ/USP, Piracicaba, São Paulo and Laboratory of Entomology and Acarology_UFAL, Arapiraca Campus.

\section{Results and discussion}

In total, 4442 mites (adults and immature individuals) were sampled in this study with 2564 found on sugarcane and 1878 on C. oblongifolia.

Mites associated with sugarcane comprised seven families (Table 1), of which family Eriophyidae showed the highest abundance (above $54 \%$ ), especially on the apical leaves (94\%). Individuals of the families Tetranychidae and Tarsonemidae occurred in higher numbers in the basal $(30 \%)$ and middle (12\%) leaves. The families Phytoseiidae, Cheyletidae, Tydeidae and Iolinidae occurred at low percentages ranging from 0.1 to 2.3 (Table 1).

On C. oblongifolia, numerous mite species were found in different strata (apical, middle and basal) at similar proportions (Table 2). As in sugarcane, most of the mites sampled 
Table 1 Total numbers and percentages of mites collected on sugarcane, in the State of Alagoas, during summer, fall and winter seasons, 2012

\begin{tabular}{|c|c|c|c|c|c|c|c|c|}
\hline \multirow[t]{2}{*}{ Taxa } & \multicolumn{2}{|c|}{ Summer } & \multicolumn{2}{|l|}{ Fall } & \multicolumn{2}{|c|}{ Winter } & \multicolumn{2}{|l|}{ Total } \\
\hline & Total & $\%$ & Total & $\%$ & Total & $\%$ & Total & $\%$ \\
\hline \multicolumn{9}{|l|}{ Apical leaf } \\
\hline \multicolumn{9}{|l|}{ Prostigmata } \\
\hline Eriophyidae & 622 & 99.0 & 82 & 75.9 & 319 & 93.0 & 1023 & 94.8 \\
\hline Tetranychidae & 6 & 1.0 & 23 & 21.3 & 14 & 4.1 & 43 & 4.0 \\
\hline Tarsonemidae & 0 & 0.0 & 0 & 0.0 & 5 & 1.5 & 5 & 0.5 \\
\hline Iolinidae & 0 & 0.0 & 3 & 2.8 & 4 & 1.2 & 7 & 0.6 \\
\hline \multicolumn{9}{|l|}{ Mesostigmata } \\
\hline Phytoseiidae & 0 & 0.0 & 0 & 0.0 & 1 & 0.3 & 1 & 0.1 \\
\hline Total & 628 & 100.0 & 108 & 100.0 & 343 & 100.0 & 1079 & 100.0 \\
\hline \multicolumn{9}{|l|}{ Middle leaf } \\
\hline \multicolumn{9}{|l|}{ Prostigmata } \\
\hline Eriophyidae & 146 & 48.0 & 77 & 35.2 & 90 & 40.0 & 313 & 41.8 \\
\hline Tetranychidae & 156 & 51.3 & 130 & 59.4 & 45 & 20.0 & 331 & 44.3 \\
\hline Tarsonemidae & 0 & 0.0 & 4 & 1.8 & 75 & 33.3 & 79 & 10.6 \\
\hline Iolinidae & 1 & 0.3 & 5 & 2.3 & 5 & 2.2 & 11 & 1.5 \\
\hline \multicolumn{9}{|l|}{ Mesostigmata } \\
\hline Phytoseiidae & 1 & 0.3 & 3 & 1.4 & 10 & 4.4 & 14 & 1.9 \\
\hline Total & 304 & 100.0 & 219 & 100.0 & 225 & 100.0 & 748 & 100.0 \\
\hline \multicolumn{9}{|l|}{ Basal leaf } \\
\hline \multicolumn{9}{|l|}{ Prostigmata } \\
\hline Eriophyidae & 122 & 73.1 & 23 & 13.7 & 51 & 13.8 & 196 & 27.8 \\
\hline Tetranychidae & 32 & 19.2 & 130 & 77.4 & 125 & 33.8 & 287 & 40.7 \\
\hline Tarsonemidae & 5 & 3.0 & 7 & 4.2 & 182 & 49.2 & 194 & 27.5 \\
\hline Iolinidae & 4 & 2.4 & 2 & 1.2 & 4 & 1.1 & 10 & 1.4 \\
\hline Tydeidae & 0 & 0.0 & 0 & 0.0 & 1 & 0.3 & 1 & 0.1 \\
\hline Cheylletidae & 1 & 0.6 & 0 & 0.0 & 0 & 0.0 & 1 & 0.1 \\
\hline \multicolumn{9}{|l|}{ Mesostigmata } \\
\hline Phytoseiidae & 3 & 1.8 & 6 & 3.6 & 7 & 1.9 & 16 & 2.3 \\
\hline Total & 167 & 100.0 & 168 & 100.0 & 370 & 100.0 & 705 & 100.0 \\
\hline \multicolumn{9}{|l|}{ Culms } \\
\hline \multicolumn{9}{|l|}{ Prostigmata } \\
\hline Tarsonemidae & 0 & 0.0 & 0 & 0.0 & 3 & 33.3 & 3 & 21.4 \\
\hline Astigmatina & 0 & 0.0 & 3 & 60.0 & 1 & 11.1 & 4 & 28.6 \\
\hline Oridatida & 0 & 0.0 & 2 & 40.0 & 5 & 55.6 & 7 & 50.0 \\
\hline Total & 0 & 0.0 & 5 & 100.0 & 9 & 100.0 & 14 & 100.0 \\
\hline
\end{tabular}

(over $69 \%$ ) were classified as Eriophyidae. The families Tarsonemidae and Ascidae occurred at percentages greater than $5 \%$ in the summer and winter samples, but this percentage was reduced in the fall. The families Phytoseiidae, Stigmaeidae, Tetranychidae, Tenuipalpidae, Tydeidae, Iolinidae, Eupalopsellidae, Eupodidae and Cunaxidae occurred in percentages between 0.1 and $2.4 \%$ in all of the samples (Table 2). 
Table 2 Total numbers and percentages of individuals classified into the predominant mite families sampled on Cupania oblongifolia from Atlantic forest fragments in the State of Alagoas, during summer, fall and winter seasons, 2012

\begin{tabular}{|c|c|c|c|c|c|c|c|c|}
\hline \multirow[t]{2}{*}{ Taxa } & \multicolumn{2}{|c|}{ Summer } & \multicolumn{2}{|l|}{ Fall } & \multicolumn{2}{|c|}{ Winter } & \multicolumn{2}{|l|}{ Total } \\
\hline & Total & $\%$ & Total & $\%$ & Total & $\%$ & Total & $\%$ \\
\hline \multicolumn{9}{|l|}{ Apical leaf } \\
\hline \multicolumn{9}{|l|}{ Prostigmata } \\
\hline Eriophyidae & 46 & 35.1 & 269 & 82.5 & 176 & 70.1 & 491 & 69.4 \\
\hline Tarsonemidae & 7 & 5.3 & 4 & 1.2 & 13 & 5.2 & 24 & 3.4 \\
\hline Stigmaeidae & 3 & 2.3 & 0 & 0.0 & 6 & 2.4 & 9 & 1.3 \\
\hline Cunaxidae & 2 & 1.5 & 1 & 0.3 & 0 & 0.0 & 3 & 0.4 \\
\hline Iolinidae & 2 & 1.5 & 2 & 0.6 & 0 & 0.0 & 4 & 0.6 \\
\hline Tetranychidae & 0 & 0.0 & 0 & 0.0 & 2 & 0.8 & 2 & 0.3 \\
\hline Eupalopsellidae & 0 & 0.0 & 0 & 0.0 & 2 & 0.8 & 2 & 0.3 \\
\hline Tenuipalpidae & 0 & 0.0 & 1 & 0.3 & 0 & 0.0 & 1 & 0.1 \\
\hline Tydeidae & 0 & 0.0 & 2 & 0.6 & 0 & 0.0 & 2 & 0.3 \\
\hline Eupodidae & 1 & 0.8 & 0 & 0.0 & 0 & 0.0 & 1 & 0.1 \\
\hline \multicolumn{9}{|l|}{ Mesostigmata } \\
\hline Ascidae & 11 & 8.4 & 8 & 2.5 & 12 & 4.8 & 31 & 4.4 \\
\hline Phytoseiidae & 4 & 3.1 & 0 & 0.0 & 1 & 0.4 & 5 & 0.7 \\
\hline Astigmatina & 16 & 12.2 & 4 & 1.2 & 5 & 2.0 & 25 & 3.5 \\
\hline Oribatida & 39 & 29.8 & 35 & 10.7 & 34 & 13.5 & 108 & 15.3 \\
\hline Total & 131 & 100.0 & 326 & 100.0 & 251 & 100.0 & 708 & 100.0 \\
\hline \multicolumn{9}{|l|}{ Middle leaf } \\
\hline \multicolumn{9}{|l|}{ Prostigmata } \\
\hline Eriophyidae & 12 & 14.0 & 214 & 74.3 & 108 & 51.2 & 334 & 57.1 \\
\hline Tarsonemidae & 10 & 11.6 & 1 & 0.3 & 21 & 10.0 & 32 & 5.5 \\
\hline Stigmaeidae & 4 & 4.7 & 4 & 1.4 & 4 & 1.9 & 12 & 2.1 \\
\hline Cunaxidae & 3 & 3.5 & 1 & 0.3 & 0 & 0.0 & 4 & 0.7 \\
\hline Iolinidae & 2 & 2.3 & 3 & 1.0 & 0 & 0.0 & 5 & 0.9 \\
\hline Tetranychidae & 1 & 1.2 & 1 & 0.3 & 0 & 0.0 & 2 & 0.3 \\
\hline Eupalopsellidae & 0 & 0.0 & 0 & 0.0 & 2 & 0.9 & 2 & 0.3 \\
\hline Tydeidae & 1 & 1.2 & 0 & 0.0 & 0 & 0.0 & 1 & 0.2 \\
\hline Cheylletidae & 0 & 0 & 1 & 0.3 & 1 & 0.5 & 2 & 0.3 \\
\hline \multicolumn{9}{|l|}{ Mesostigmata } \\
\hline Ascidae & 10 & 11.6 & 8 & 2.8 & 24 & 11.4 & 42 & 7.2 \\
\hline Phytoseiidae & 4 & 4.7 & 4 & 1.4 & 8 & 3.8 & 16 & 2.7 \\
\hline Astigmatina & 17 & 19.8 & 2 & 0.7 & 4 & 1.9 & 23 & 3.9 \\
\hline Oribatida & 22 & 25.6 & 49 & 17.0 & 39 & 18.5 & 110 & 18.8 \\
\hline Total & 86 & 100.0 & 288 & 100.0 & 211 & 100.0 & 585 & 100.0 \\
\hline \multicolumn{9}{|l|}{ Basal leaf } \\
\hline \multicolumn{9}{|l|}{ Prostigmata } \\
\hline Eriophyidae & 78 & 58.2 & 68 & 53.1 & 193 & 77.5 & 339 & 66.3 \\
\hline Tarsonemidae & 1 & 0.7 & 2 & 1.6 & 8 & 3.2 & 11 & 2.2 \\
\hline Stigmaeidae & 0 & 0.0 & 0 & 0.0 & 1 & 0.4 & 1 & 0.2 \\
\hline
\end{tabular}


Table 2 continued

\begin{tabular}{|c|c|c|c|c|c|c|c|c|}
\hline \multirow[t]{2}{*}{ Taxa } & \multicolumn{2}{|c|}{ Summer } & \multicolumn{2}{|l|}{ Fall } & \multicolumn{2}{|c|}{ Winter } & \multicolumn{2}{|l|}{ Total } \\
\hline & Total & $\%$ & Total & $\%$ & Total & $\%$ & Total & $\%$ \\
\hline Cunaxidae & 2 & 1.5 & 3 & 2.3 & 0 & 0.0 & 5 & 1.0 \\
\hline Iolinidae & 2 & 1.5 & 2 & 1.6 & 0 & 0.0 & 4 & 0.8 \\
\hline Tetranychidae & 2 & 1.5 & 0 & 0.0 & 0 & 0.0 & 2 & 0.4 \\
\hline Eupalopsellidae & 1 & 0.7 & 0 & 0.0 & 0 & 0.0 & 1 & 0.2 \\
\hline Tenuipalpidae & 1 & 0.7 & 0 & 0.0 & 0 & 0.0 & 1 & 0.2 \\
\hline Eupodidae & 1 & 0.7 & 1 & 0.8 & 0 & 0.0 & 2 & 0.4 \\
\hline Bdellidae & 1 & 0.7 & 0 & 0 & 0 & 0.0 & 1 & 0.2 \\
\hline \multicolumn{9}{|l|}{ Mesostigmata } \\
\hline Ascidae & 4 & 3.0 & 5 & 3.9 & 14 & 5.6 & 23 & 4.5 \\
\hline Phytoseiidae & 2 & 1.5 & 0 & 0.0 & 4 & 1.6 & 6 & 1.2 \\
\hline Astigmatina & 10 & 7.5 & 1 & 0.8 & 3 & 1.2 & 14 & 2.7 \\
\hline Oribatida & 29 & 21.6 & 46 & 35.9 & 26 & 10.4 & 101 & 19.8 \\
\hline Total & 134 & 100.0 & 128 & 100.0 & 249 & 100.0 & 511 & 100.0 \\
\hline
\end{tabular}

The higher number of mites associated with sugarcane was collected during the summer, a period of lower rainfall, whereas lower numbers were collected in the fall and winter, which are periods with higher rainfall (Table 1). In contrast, on C. oblongifolia, the higher number of mites was collected during the fall and winter. This pattern is most likely due to the higher number of eriophyids found in fall and winter (Table 2).

For $C$. oblongifolia, the eriophyid mites were mostly found protected within leaf domatia on the abaxial surface. Moreover, the $C$. oblongifolia trees were under the canopy of the forest, which protects lower plants from the direct impact of rainfall. This protection may have prevented the rain from reducing Eriophyidae populations on C. oblongifolia. On sugarcane, however, individuals were more exposed because they inhabit leaf surface.

Romero and Benson (2005) also observed unidentified Eriophyidae mites associated with leaf domatia on $C$. vernalis. Those authors reported that these mites blocked the opening of the domatia with exuvia in combination with silk, possibly as an additional protection against predation. In the present study some domatia with mite exuvia blocking their entrances were also observed.

Mites classified into Tarsonemidae, Eriophyidae, Tetranychidae, Phytoseiidae and Ascidae families were identified to the genus and/or species levels, except for the Eriophyidae collected on $C$. oblongifolia, which were identified to the tribe level because they are new genera/species. Individuals of the Tenuipalpidae, Cheyletidae, Stigmaeidae, and Eupalopsellidae families were identified to the genus level. Individuals of the Cunaxidae, Tydeidae, Iolinidae, Bdellidae and Eupodidae families could not be identified to the genus or species level due to the reduced number and development stage of individuals collected and due to the positions in which some specimens were mounted (Table 3).

The families Tarsonemidae, Eriophyidae, Phytoseiidae and Tetranychidae showed the highest species richness in the two areas where the study was conducted. The families Cheyletidae, Stigmaeidae, Eupalopsellidae and Ascidae were represented by only one species each.

The family Tarsonemidae had the highest species richness (nine species), of which Tarsonemus sp. 2, Tarsonemus sp. 3 and Neotarsonemoide sp. are common to both plant 
Table 3 Total genera and species/morphospecies of mites identified on Cupania oblongifolia and sugarcane in the State of Alagoas, Brazil, during summer, fall and winter seasons, 2012

\begin{tabular}{|c|c|c|c|}
\hline Plant family/species & Mite family & Mite species & No. of specimens \\
\hline \multicolumn{4}{|l|}{ Poaceae } \\
\hline \multirow[t]{11}{*}{ Saccharum officinarum } & Eriophyidae & Abacarus spp. & 1532 \\
\hline & Tetranychidae & Monoceronychus linki & 576 \\
\hline & & Oligonychus sp.1 & 3 \\
\hline & Tarsonemidae & Neotarsonemoide sp. & 1 \\
\hline & & Tarsonemus sp. 2 & 10 \\
\hline & & Tarsonemus sp.3 & 7 \\
\hline & & Tarsonemus aff. cornus sp.2 & 15 \\
\hline & Cheylletidae & Paracheyletiella sp. & 1 \\
\hline & Phytoseiidae & Amblyseius tamatavensis ${ }^{\mathrm{b}}$ & 1 \\
\hline & & Typhlodromips mangleae ${ }^{\mathrm{b}}$ & 1 \\
\hline & & Neoseiulus anonymus & 1 \\
\hline \multicolumn{4}{|l|}{ Sapindaceae } \\
\hline \multirow[t]{23}{*}{ Cupania oblongifolia } & Eriophyidae & Colopodacini/Colomerini $^{\mathrm{a}}$ & 1164 \\
\hline & Tetranychidae & Oligonychus sp.2 & 1 \\
\hline & & Atrichoproctus sp. & 1 \\
\hline & Tarsonemidae & Tarsonemus sp.1 & 3 \\
\hline & & Tarsonemus $\mathrm{sp} .2^{\mathrm{b}}$ & 7 \\
\hline & & Tarsonemus sp.3 & 1 \\
\hline & & Tarsonemus aff. cornus sp.1 & 7 \\
\hline & & Neotarsonemoide sp. & 4 \\
\hline & & Xenotarsonemus sp.1 & 3 \\
\hline & & Metatarsonemus sp. & 3 \\
\hline & & Daidalotarsonemus sp. & 3 \\
\hline & & Fungitarsonemus lodici & 2 \\
\hline & Tenuipalpidae & Tenuipalpus sp. & 5 \\
\hline & & Brevipalpus sp. & 2 \\
\hline & & Ultratenuipalpus sp. & 1 \\
\hline & Eupalopsellidae & Exothorhis sp. & 1 \\
\hline & Stigmaeidae & Agistemus sp. & 16 \\
\hline & Cheylletidae & Paracheyletiella sp. ${ }^{\mathrm{b}}$ & 2 \\
\hline & Phytoseiidae & Amblyseius euterpes & 5 \\
\hline & & Amblyseius operculatus & 1 \\
\hline & & Amblyseius tamatavensis ${ }^{\mathrm{b}}$ & 1 \\
\hline & & Typhlodromips mangleae ${ }^{\mathrm{b}}$ & 1 \\
\hline & Ascidae & Asca aff. capria & 61 \\
\hline
\end{tabular}

\footnotetext{
a Tribes of eriophyidae

b Species common to sugarcane crop and C. oblongifolia
}

species studied (sugarcane and C. oblongifolia). Most of the tarsonemids found are fungivorous, or their food habits have not been thoroughly characterized, and they are not considered pests. 
Four of the six Eriophyidae species collected were found on $C$. oblongifolia, and the other two were found on sugarcane. The four species observed on C. oblongifolia were identified as new to science; they belong to the tribes Colopodacini and Colomerini and are in the process of being described.

The two Eriophyidae species sampled on sugarcane were of the genus Abacarus Keifer. Abacarus sacchari Channabasavanna had already been reported in Brazil by Flechtmann and Aranda (1970) but only in the state of São Paulo. Therefore, this is the first record of $A$. sacchari in the state of Alagoas. The other Abacarus species is morphologically different from A. sacchari and may be a new species (to be confirmed). Mites of this genus are not currently considered pests of sugarcane in Brazil (Moraes and Flechtmann 2008). However, severe symptoms of the attack of two Abacarus species on sugarcane crops have been observed in some countries-Abacarus queenslandiensis Ozman-Sullivan, Amrine and Walter reported in Australia (Ozman-Sullivan et al. 2006); and Abacarus doctus Navia and Flechtmann, in Costa Rica (Aguilar et al. 2010; Navia et al. 2011) and El Salvador (Guzzo et al. in press). At high population levels, A. doctus may cause reddish or tan spots that spread randomly on the surfaces of the leaves. These symptoms may be confused with those caused by the fungi Puccinia spp., which are common in sugarcane crops and cause rust (Aguilar et al. 2010; Navia et al. 2011). The symptoms apparently caused by the new Abacarus species observed in this study are similar to those reported by Aguilar et al. (2010) and Navia et al. (2011), and they may be mistaken by agronomists and farmers for fungi symptoms. These symptoms have previously been observed in most sugarcane fields in Alagoas State.

The mite Monoceronychus linki Pritchard and Baker, a tetranychid found in sugarcane crops, was reported for the first time in the State of Pernambuco, Brazil, by Flechtmann and Baker (1975). Symptoms caused by the attack of this mite on sugarcane have not been reported. In that study, $M$. linki was observed mainly on the abaxial surface of middle and basal leaves, especially near the midrib. Additionally, no damage caused by the species could be characterized.

A number of tetranychids of the genus Oligonychus Berlese were also sampled on the abaxial side of sugarcane leaves, producing web. In the present study, no symptoms caused by tetranychids were observed. Two mites of the genus Oligonychus, O. grypus and $O$. pratensis, have been reported on sugarcane crops in Brazil. According to Moraes and Flechtmann (2008), O. grypus was reported (A. Mendonça, unpublished) at high population levels in an extensive area in the State of Maranhão, where the plants were in the early development stage during the dry season. Oligonychus grypus was also reported at high population levels in the State of São Paulo (Almeida et al. 2009). This species was observed to cause significant damage to sugarcane crops in both studies.

In the present study, the family Tenuipalpidae was represented by the genera Brevipalpus Donnadieu, Tenuipalpus Donnadieu and Ultratenuipalpus Mitrofanov, which were observed only on $C$. oblongifolia, on the abaxial surface of the leaves, and in very limited numbers. In contrast, Castro and Moraes (2007) reported that the family Tenuipalpidae was the most abundant phytophagous mite family in a study conducted in Atlantic forest in the State of São Paulo. The Tenuipalpidae family was mainly represented by a Brevipalpus morphospecies. However, it is worth mentioning that the study by Castro and Moraes (2007) was conducted with plants of other families, mostly Lauraceae.

The predatory mite Asca aff. capria (Ascidae) was found only on C. oblongifolia. Romero et al. (2011) also reported the occurrence of Asca sp. and of other phytophagous and predatory mite species associated with domatia in coffee leaves. Some species belonging to the genera Lasioseius spp. and Asca spp. are frequently observed in association 
with Eriophyoidea and Tenuipalpidae, and they can be used to control Eriophyoidea and Tenuipalpidae populations (Walter et al. 1993). More detailed studies should be performed to investigate whether $A$. aff. capria is a predator of eriophyids on $C$. oblongifolia domatia or if $A$. aff. capria and eriophyids compete for niche space.

The family Phytoseiidae comprises the main group of mites that prey on other mites and small insects, and it has received great attention from the scientific community due to its potential in biological control (Gerson et al. 2003; Demite et al. 2014). Several species are significant biological control agents for important groups of phytophagous mites, including Tetranychidae, Tenuipalpidae, Tarsonemidae and Eriophyoidea (Gerson et al. 2003). In the present study, the Phytoseiidae was represented by five species, two of them common on both sugarcane crop and C. oblongifolia trees: Amblyseius tamatavensis Blommers and Typhlodromips mangleae De Leon. Neoseiulus anonymus (Chant and Baker) was observed only on sugarcane, and Amblyseius euterpes Gondim and Moraes and Amblyseius operculatus De Leon were observed exclusively on C. oblongifolia.

Lofego et al. (2009) reported the occurrence of the phytoseiids $N$. anonymus and $T$. mangleae associated with plant species of the family Poaceae (sugarcane family) in the state of São Paulo. Lofego et al. (2004) also observed mites of the genera Amblyseius Berlese and Neoseiulus Hugles, and the species T. mangleae (Phytoseiidae) associated with mites of the genus Abacarus (Eriophyidae) on guava trees (Psidium guajava L.) (Myrtaceae) in the state of São Paulo. It is possible that the predatory mites found in the present study belonging to these genera are predators of mites of the Eriophyidae, predominant family on both sugarcane and $C$. oblongifolia.

Silva et al. (2010) reported the occurrence of $T$. mangleae associated with coffee plantations and of $A$. operculatus associated with coffee plantations and with the natural vegetation in the forest fragments surrounding the crops in the state of Minas Gerais. In the present study, T. mangleae was observed in the sugarcane area as well as in the Atlantic forest fragment. A. operculatus was observed only in the forest area. Silva et al. (2010) also reported that the mites common in agroecosystems such as coffee plantations and in the surrounding native vegetation indicate that the natural environments are hosts to predatory mites that likely spontaneously migrate to these agroecosystems and help naturally control pest mites. In the present study, species common to both ecosystems (sugarcane crops and caboatã trees in the Atlantic forest) were also observed.

Several studies have emphasized the influence of forest remnants over mite fauna of permanent crops, as for example on rubber cultivation (Demite and Feres 2008; Demite et al. 2013). However little is known regarding the influence of the natural vegetation on the occurrence and distribution of mites in annual crops (Demite and Feres 2005). In a recent study Rezende et al. (2014) evaluated the composition of mite communities in soybean crops and adjacent Cerrado fragments in Central Brazil and determined the existence of share species between these two areas determine similarity in an area of Cerrado and soybean fields. These authors observed that Cerrado fragments do not shelter pest species that may attack soybean and can contribute to the increase of possible predator species in this agroecosystem; all the species of predatory mites in the Phytoseiidae recorded in soybean were also found in the Cerrado fragments. Similar results were obtained in this study. No phytophagous species were common to both sugarcane and $C$. oblongifolia. However two predatory mites were shared between host plants.

Although in this study we evaluated mites associated with only one native species in the forest fragment, C. oblongifolia, our preliminary results suggest Atlantic forest native vegetation can present an important role in the sugarcane agricultural system as a source of natural enemies which can help to control phytohagous species in the crop. Therefore, 
although most species found in the present study are not considered agricultural pests, the interaction between the two environments reinforces the notion that natural environments may be reservoirs for different groups of mites. This positive influence should be further investigated through more detailed ecological studies on the interaction of mites associated with sugarcane crops and with the natural vegetation. Moreover, it would be extremely important to investigate the mites associated with other native plants occurring in the fragments.

Acknowledgments To Coordenação de Aperfeiçoamento de Pessoal de Nível Superior (CAPES), for granting the fellowship to the first author. To Prof. Dr. Gilberto José de Moraes to have received the first author at the Laboratório de Acarologia da Escola Superior de Agricultura (ESALQ) to perform the identifications. To Prof. Dr. Carlos HW Flechtmann by identifying a genera of Tetranychidae. To Prof. Dr. Antônio Carlos Lofego by identifying Tarsonemidae. To Dr. Perterson Demite for help in identifying the Phytoseiidae. To Renan Venâcio for help in identifying Tenuipalpidae. To, the Phd student Jandir Cruz Santos for help in confirmation the classification of other families. To Marcela Regina Melo Daher, representative of Usinas Reunidas Seresta by the authorization to mite sampling in their private area.

\section{References}

Aguilar H, Sanabria C, Murillo P (2010) Distribution and damage caused by Abacarus sp. (Acari: Eriophyidae) associated to sugarcane in Costa Rica. In: Moraes GJ, Castilho RC, Flechtmann CHW (eds). Astract book, Recife

Almeida LC, Moraes GJ, Chabregas SM, Arrigoni EB (2009) Primeiro relato de Oligonychus gripus em cana-de-açúcar no Estado de São Paulo. Revista de Agricultura 84:173-174

Barroso GM (1991) Sistemática de angiospermas do Brasil. UFV, Viçosa

Brandão M, Laca-Buendia JP, Macedo JF (2002) Arvores nativas e exóticas do estado de Minas Gerais. Epamig, Belo Horizonte

Castro TMMG, Moraes GJ (2007) Mite diversity on plants of different families found in the Brazilian Atlantic forest. Neotrop Entomol 36:774-782

Conab (2013) Acompanhamento de safra brasileira: cana-de-açúcar, terceiro levantamento, agosto/2013. Companhia Nacional de Abastecimento, Brasília. http://www.conab.gov.br. Accessed 14 Aug 2014

Demite PR, Feres JF (2005) Influência de Vegetação Vizinha na Distribuição de Ácaros em Seringal (Hevea brasiliensis Muell. Arg., Euphorbiaceae) em São José do Rio Preto. Neotrop Entomol 34:829-836

Demite PR, Feres RJF (2008) Influência de fragmentos de cerrado na distribuição de ácaros em seringal. Neotrop Entomol 37:196-204

Demite PR, Lofego AC, Feres RJF (2013) Mite (Acari; Arachnida) diversity of two native plants in fragments of Semideciduous Seasonal Forest in Brazil. Syst Biodivers 11:141-148

Demite PR, Mcmurtry JA, Moraes GJ (2014) Phytoseiidae database: a website for taxonomic and distributional information on phytoseiid mites (Acari). Zootaxa 3795:571-577

Flechtmann CHW, Aranda BRC (1970) New records and notes on Eriophyid mites from Brazil and Paraguay, with a list of Eriophyidae from South America. Proc Entomol Soc Wash 72:94-98

Flechtmann CHW, Baker EW (1975) A report on the Tetranychidae (Acari) of Brazil. Rev Brasileira de Entomol 19:111-122

Gerson U, Smiley RL, Ochoa R (2003) Mites (Acari) for pest control. Blackwell Science, Oxford

Heculano ACM, Matos WR (2008) Levantamento das espécies de Sapindáceas arbóreas no Estado do Rio de Janeiro. Saúde e Ambiente em Revista 3:76-85. http://www.unigranrio.br/unidades_acad/ibc/sare/ V03N01/galleries/downloads/artigos/A03N01P07.pdf. Accessed 16 Apr. 2013

Hoy MA (2011) Agricultural acarology: introdution to integrated mite management. CRC Press, Boca Raton Krantz GW, Walter DE (2009) A manual of acarology. Texas Tech University Press, Lubbock

Lofego AC, Moraes GJ, Castro LAS (2004) Phytoseiid mites (Acari: Phytoseiidae) on Myrtaceae in the State of São Paulo, Brazil. Zootaxa 516:1-18

Lofego AC, Demite PR, Kishimoto RG, Moraes GJ (2009) Phytoseiid mites on grasses in Brazil (Acari: Phytoseiidae). Zootaxa 2240:41-59

Lorenzi H (2000) Árvores brasileiras: manual de identificação e cultivo de plantas arbóreas nativas do Brasil. Plantarum, São Paulo, Nova Odessa 
Lorenzi H, Souza VC (2008) Botânica sistemática: guia ilustrado para identificação das famílias de Fanerógamas nativas e exóticas no Brasil, baseado no APG II. Plantarum, São Paulo, Nova Odessa

Ministério do Meio Ambiente (2006) Diversidade biológica e conservação da floresta atlântica ao norte do Rio São Francisco. MMA, Brasília. http://www.ima.al.gov.br. Accessed 18 Oct. 2012

Moraes JG, Flechtmann CHW (2008) Manual de acarologia-acarologia básica e ácaros de plantas cultivadas no Brasil. Holos, Ribeirão Preto

Moraes JG, Zacarias M (2000) Use of predatory mites for the control of eriophyid mites. In: Fernando LCP, Moares JG, Wickramananda IR (ed). Proceending of the international workshop on coconut mite (Aceria guerreronis). Coconut research Institute, Lunuwila, Sri Lanka, pp78-88

Navia D, Flechtmann CHW, Lindquist EE, Aguilar H (2011) A new species of Abacarus (Acari: Prostigmata: Eriophyidae) damaging sugarcane, Sacharrum officinarum L., from Costa Rica-the first eriophyoid mite described with a tibial seta on leg II. Zootaxa 3025:51-58

Ozman-Sullivan SK, Amrine JW Jr, Walter DE (2006) A new species of Eriophyoid mite (Acari: Eriophyidae) on sugarcane in Australia. Int J Acarol 32:384-395. doi:10.1080/01647950608684487

Rezende JM, Lofego AC, Nuvoloni FM, Navia D (2014) Mites from Cerrado fragments and adjacent soybean crops: does the native vegetation help or harm the plantation? Exp Appl Acarol. doi:10.1007/ s10493-014-9844-5

Romero GQ, Benson WW (2005) Biotic interactions of mites, plants and leaf domatia. Curr Opin Plant Biol 8:436-440. doi:10.1016/j.pbi.2005.05.006

Romero GQ, Dau RD, Salomão AT, Martins LF, Feres RJF, Benson WW (2011) Mites and leaf domatia: no evidence of mutualism in Coffea arabica plants. Biota Neotropical 11:27-34

Silva EA, Reis PR, Zacarias MS, Marafeli PP (2010) Fitoseídeos (Acari: Phytoseiidae) associados a cafezais e fragmentos florestais vizinhos. Ciência e Agrotecnologia 34:1146-1153. doi:10.1590/S141370542010000500010

Walter DE, Halliday RB, Lindquist EE (1993) A review of the genus Asca (Acarina: Ascidae) in Australia, with descriptions of three new leafinhabiting species. Invertebr Taxon 7:1327-1347. doi:10.1071/ IT9931327 